This method was first tried experimentally in dogs and subsequently used in 42 patients suffering from duodenal ulcers. A vagotomy was carried out at the same time.

Early and long-term results after from 7 months to 3 years are described and the advantages of this method over other methods which are used nowadays, are discussed.

Zusammenfassung. Die Arbeit betrifft eine neue Methode der Pyloroplastik, wobei der Pylorussphincter des Magens durch eine „Y-artige“ Incision durch alle Schichten bis ins Lumen des Pylorus durchgeführt wird. Nach querer Vernähung der Öffnung bekommt man eine „V-artige“ Naht, wobei ein Magenlappen dazwischenkommt bei dem eröffneten Duodenum. Die Methode wurde zuerst experimentell bei Hunden durchgeführt und anschließend bei 42 Patienten, die an Ulcus Duodenum litten, mit gleichzeitiger Vagotomie.

Es werden die Früh- und Spätresultate von 7 Monaten bis zu 3 Jahren beschrieben und die Vorteile dieser Methode gegenüber den anderen bis heute angewandten diskutiert.

Sitzungsleiter: Ich glaube, die Methode ist eines Versuchs wert.

\title{
95. Komplikationen nach Magengeschwüren in Abhängigkeit von der Infusionstherapie
}

\author{
R. M. Konrad*, V. Berndt, U. Ammedick \\ und B. NowotnY-Düsseldorf
}

\section{Complications after Gastric Ulcer in Connexion with Infusion Therapy}

Summary. Based on the results of alimentary therapy after resection of the stomach for gastric and duodenal ulcer in 1147 patients, the frequency of complications connected with the protein metabolism is demonstrated. Considering the considerable differences in age it was seen that patients with amino-acid infusions showed only a slight increase in the rate of complications despite higher age compared with inadequately fed younger patients. There were statistically confirmed differences with regard to the time of discharge and loss of weight. The difficulties in obtaining positive clinical criteria of the efficacy of postoperative parenteral feeding are pointed out.

Zusammenfassung. Anhand der postoperativen Ernährungstherapie von 1147 Patienten nach Magenresektion wegen Magen- und Zwölffingerdarmgeschwüren wurde die Häufigkeit der Komplikationen, welche in Abhängigkeit vom Eiweiß. haushalt stehen, aufgezeigt. Es ergab sich unter Berücksichtigung der erheblichen Altersverschiebung, daß Patienten mit Aminosäuren-Infusionen trotz höheren Lebensalters nur eine geringe Zunahme der Komplikationsrate gegenüber mangelhaft ernährten jüngeren Patienten hatten. Statistisch gesicherte Unterschiede fanden sich hinsichtlich des Entlassungstermines und des Gewichtsverlustes. Auf die Schwierigkeiten, positive klinische Kriterien für die Effizienz einer postopera. tiven parenteralen Ernährung zu erhalten, wurde hingewiesen. 